\title{
Corrigendum: Detection of Aflatoxins in Different Matrices and Food-Chain Positions
}

\section{OPEN ACCESS}

Edited and reviewed by: Javier Carballo,

University of Vigo, Spain

${ }^{*}$ Correspondence: Gabriella Miklós

miklosg@nebih.gov.hu

Specialty section This article was submitted to

Food Microbiology,

a section of the journal

Frontiers in Microbiology

Received: 19 February 2021 Accepted: 13 April 2021 Published: 13 May 2021

Citation:

Miklós G, Angeli C, Ambrus Á,

Nagy A, Kardos $V$, Zentai $A$, Kerekes K, Farkas Z, Józwiak Á and

Bartók T (2021) Corrigendum: Detection of Aflatoxins in Different Matrices and Food-Chain Positions.

Front. Microbiol. 12:669714. doi: 10.3389/fmicb.2021.669714
Gabriella Miklós ${ }^{1 *}$, Cserne Angeli ${ }^{2}$, Árpád Ambrus ${ }^{3}$, Attila Nagy $^{4}$, Valéria Kardos ${ }^{4}$, Andrea Zentai ${ }^{5}$, Kata Kerekes ${ }^{5}$, Zsuzsa Farkas ${ }^{6}$, Ákos Józwiak ${ }^{6}$ and Tibor Bartók ${ }^{2}$

${ }^{1}$ Székesfehérvár Regional Food Chain Laboratory, National Food Chain Safety Office, Székesfehérvár, Hungary, ${ }^{2}$ Fumizol Ltd., Szeged, Hungary, ${ }^{3}$ University of Debrecen Doctoral School of Nutrition and Food Sciences, Debrecen, Hungary, ${ }^{4}$ Food Chain Safety Laboratory Directorate, National Food Chain Safety Office, Budapest, Hungary, ${ }^{5}$ System Management and Supervision Directorate, National Food Chain Safety Office, Budapest, Hungary, ${ }^{6}$ Digital Food Institute, University of Veterinary Medicine Budapest, Budapest, Hungary

Keywords: aflatoxins, LOD, LOQ, limits, extraction, clean-up, analysis, detection

\section{A Corrigendum on}

Detection of Aflatoxins in Different Matrices and Food-Chain Positions by Miklós, G., Angeli, C., Ambrus, Á., Nagy, A., Kardos, V., Zentai, A., et al. (2020). Front. Microbiol. 11:1916. doi: 10.3389/fmicb.2020.01916

In the original article, there was a mistake in Figure 2 as published. In the figure caption, the word "semantic" should be replaced by "schematic." Additionally, Figure $\mathbf{2}$ has been corrected and replaced. The corrected figure and caption appear below.

In the original article, there was an error in the section heading "Chromatin Interacting ProteinMass Spectrometry (Chip-MS)." Instead of "Chromatin Interacting Protein-Mass Spectrometry (Chip-MS)" it should be "Chip-MS." A correction has been made to Hyphenated Techniques, Chromatin Interacting Protein-Mass Spectrometry (Chip-MS).

Additionally, in the original article, there was an error in the section heading "Matrix-Assisted Laser Desorption Ionization-Time of Flight-Mass Spectroscopy (MALDI-TOF-MS)." Instead of "Matrix-Assisted Laser Desorption Ionization-Time of Flight-Mass Spectroscopy (MALDI-TOF-MS)" it should be 


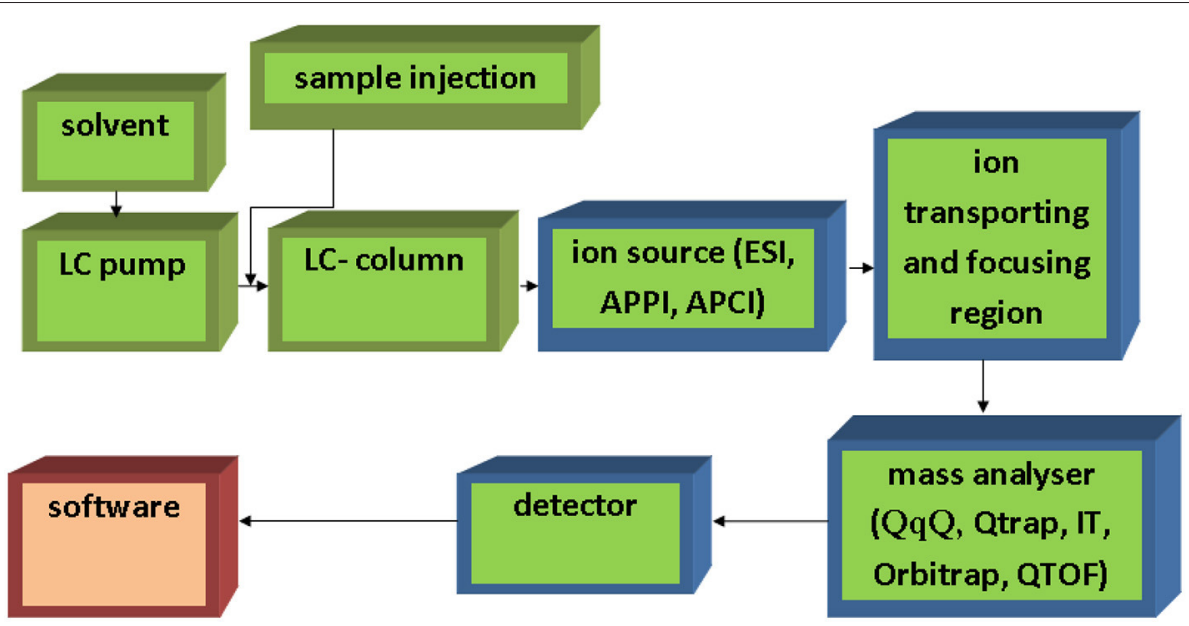

FIGURE 2 | Simple schematic of LC-MS system.

"Matrix-Assisted Laser Desorption Ionisation-Time of FlightMass Spectrometry (MALDI-TOF-MS)." A correction has been made to Other Techniques, Matrix-Assisted Laser Desorption Ionization-Time of Flight-Mass Spectroscopy (MALDI-TOF-MS).

The authors apologize for these errors and state that they do not change the scientific conclusions of the article in any way. The original article has been updated.
Copyright (C) 2021 Miklós, Angeli, Ambrus, Nagy, Kardos, Zentai, Kerekes, Farkas, Józwiak and Bartók. This is an open-access article distributed under the terms of the Creative Commons Attribution License (CC BY). The use, distribution or reproduction in other forums is permitted, provided the original author(s) and the copyright owner(s) are credited and that the original publication in this journal is cited, in accordance with accepted academic practice. No use, distribution or reproduction is permitted which does not comply with these terms. 